Volume 10, No.2, March - April 2021

International Journal of Advanced Trends in Computer Science and Engineering

Available Online at http://www.warse.org/IJATCSE/static/pdf/file/ijatcse901022021.pdf

https://doi.org/10.30534/ijatcse/2021/901022021

\title{
Analysis the Effect of Information Quality, System Quality, and Service Quality on Digital Wallet User Satisfaction of Students in Jakarta
}

\author{
Levin Immanuel Limardi Haryadi ${ }^{1}$, Jarot S. Suroso ${ }^{2}$ \\ Information Systems Management Department, BINUS Graduate Program - Master of Information Systems \\ Bina Nusantara University, Jakarta, Indonesia, 11480. \\ ${ }^{1}$ levin.haryadi@ binus.ac.id; ${ }^{2}$ jsembodo@ binus.edu
}

\begin{abstract}
The purpose of this research is to find out whether there is an effect between information quality, system quality, dan service quality on user satisfaction, and how much the effect on user satisfaction of digital wallet of students in Jakarta. This research uses quantitative methods with 100 students in Jakarta who use digital wallet as respondents. Measurement of user satisfaction is conducted based on DeLone and McLean information systems success model, which includes Information Quality, System Quality, and Service Quality. Based on research results, information quality, system quality, and service quality have significant effect on digital wallet user satisfaction of students in Jakarta with $90,1 \%$ effect percentages.
\end{abstract}

Key words : Analysis effect, user satisfaction, digital wallet, students.

\section{INTRODUCTION}

At this time, technological developments have developed rapidly. The developments of the technology have influenced many other sectors to be able to develop following the development of the technology. The transaction or payment sector is one of the sectors affected by the development of technology. The transaction or payment sector itself can be found in everyday life, where this is an activity that must be performed by humans to be able to meet the needs of life, as social beings who need each other. In fact, this transaction practice can be found and seen easily in the human life cycle to buy goods according to their needs.

A transaction is an economic or financial event involving at least 2 parties, either between 1 person or with many people, by performing exchange activities, engaging in business, and lending and borrowing activities according to the agreement between related parties based on law mutually agreed upon [1]. Based on the meaning of the transaction conveyed, it means that a transaction is an activity which includes buying and selling involving 2 or more parties, in meeting the needs of life, with the giving and receiving of money in it based on a joint decision.

As the development of the technological world which has an impact on the transaction sector, transaction methods have also undergone an evolution following the development of this technology. Electronic money is the result of technological developments in the transaction sector.

According to lokadata.beritagar.id, the increase in electronic money transactions in Indonesia from 2009-2019 continued to occur [2]. The biggest increase occurred from 2017-2019, where there was a very rapid increase in volume and nominal transactions. As of August 2019, the transaction volume has reached 3.2 billion with a transaction value of 81.9 trillion rupiah. In these 10 years, it can be concluded that electronic money is increasingly being used in transactions in the daily life of people in Indonesia. Therefore, it is not impossible that the increase in the number of transactions will continue to increase rapidly in the future.

The increased usage of these digital wallets cannot be separated from the increments in smartphone users. According to data from statista.com, smartphone users in Indonesia in 2020 will reach 191.6 million people [3]. This shows that the high number of smartphone users in Indonesia. In addition, the data displayed also states that smartphone user continues to increase every year constantly and it is projected that until 2025, smartphone users in Indonesia will reach 256.11 million users.

According to the results of research conducted by the Indonesian Internet Service Providers Association or APJII, from total population in Indonesia in 2018, namely 264.16 million, 171.17 million people or $64.8 \%$ of the total population using the internet [4]. Based on the survey, it is also shown that the top positions with the highest number of internet users are aged 15-19, 20-24, 25-29, and 30-34. In other words, it can be concluded that the use of the internet is dominated by people who are at the student and university age. According to Ipsos research related to the use of digital 
wallet payment instruments in Indonesia, it was found that as many as 68 percent of millennials use digital wallets [5].

Through the increments in the use of smartphones and the internet every year in Indonesia, make it easier for users to be able to use digital wallets as a tool to do transactions in living their daily lives. In this case, of course the digital wallet provides various facilities to be able to change transaction patterns that are generally done traditionally to switch to digital in orders to facilitate transactions to keep up with technological developments.

According to data from DailySocial.id in databoks.katadata.co.id, there are 10 digital wallets with the most users or the most widely used in Indonesia during 2019 [6]. Of the 10 digital wallets, Gopay, OVO, Dana, and LinkAja occupy the top positions and is proven to attract more users to use the digital wallet. The percentages of digital wallet usage are Gopay (83.3\%), OVO (81.4\%), Dana (68.2\%), and LinkAja (53\%).

Through this data, can be seen that the use of digital wallets will increase every year in Indonesia and of course the more reliable it is in carrying out daily transactions. Through the data, it can also be concluded that students are the largest group in using these digital wallets. Transaction transformation through digital wallets is also oriented, of course, to the satisfaction of its users in using digital wallets as a tool for transactions to meet their daily needs.

Therefore, the researcher wants to research related to the satisfaction of digital wallet users of students in Jakarta by using three dimensions as benchmarks, namely: information quality, system quality, and service quality. Based on this, the authors would like to conduct research related to the effect of information quality, system quality, and service quality on digital wallet user satisfaction of students in Jakarta. Through the research results obtained, researchers hope to be able to provide new insights and knowledge related to how the effect of information quality, system quality, and service quality on digital wallet user satisfaction of students in Jakarta.

The purpose of this research is to find out whether there is an effect between information quality, system quality, dan service quality on user satisfaction, and how much the effect on user satisfaction of digital wallet of students in Jakarta. In this research, quantitative research methods will be used. The required data will be traced through journals and articles related to the research that will be carried out. Once completed, a questionnaire will be created, which is based on DeLone and McLean's success model using 3 dimensions, namely: information quality, system quality, and service quality as a measure of user satisfaction. After the questionnaire is generated, it will be distributed randomly to students in Jakarta who use digital wallets to make transactions. After the data is successfully obtained, data processing and analysis will be carried out to get the desired results.

\section{LITERATURE REVIEW \& HYPOTHESIS}

\subsection{Information System}

The information system is a system in an organization that can be used to meet various needs to process daily transactions in the operations of an organization, which has a managerial nature, with adjustments to the strategic cycle of the organization so that it can be used for decision making by providing the information needed by related parties [7]. Technically, information systems are defined as a set of components that are interconnected with each other, responsible for accommodating and distributing information for better decision making, helping to analyze organizational problems, describing complex matters, and creating new products to support an organization's strategy [8]. With the explanation of information systems above, it can be explained that an information system is a combination of components that include systems and procedures that have been organized to support decision making in order to achieve certain goals.

With the development of technology over time, the use of information systems, especially in the field of transactions via digital wallets, is increasingly helping users to be able to access the system in orders to obtain the desired information and carry out the payment process according to determined decisions.

\subsection{Information System Success Model}

In measuring information systems successfulness, there have been various studies conducted in orders to obtain model factors in influencing the success of the information system. One of the many studies related to information systems success models is research conducted by DeLone and McLean.

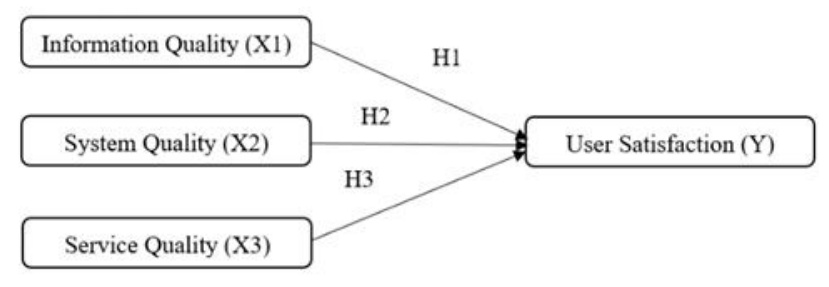

Figure 1: Research Model

\section{A. Information Quality}

The quality of information is used to measure success in terms of semantics [9]. Semantic success is the success of the system in its accuracy in conveying information to users. The quality of information can be measured through the following indicators: 
1. Completeness, completeness in the quality of information includes all information in using the information system required by the user.

2. Accuracy, accuracy in the quality of information includes the accuracy of the correctness of information by an information system which of course must be accurate to be used as a basis for making decisions.

3. Punctuality, timeliness in the quality of information includes information delivered on time. With the information delivered on time, the process of making decisions can be carried out well.

4. Relevance, relevance in the quality of information includes the ability of information systems to meet the needs of users. Every information needs to be conveyed in a relevant way in orders to assist users in making decisions.

H1: There is a significant effect between variable information quality on digital wallet user satisfaction of students in Jakarta.

\section{B. System Quality}

System quality is used to measure technical success [9]. With a good system, of course it can affect the level of use of a system. The system quality measurement can be through the following indicators:

1. Ease of Use, with the ease of use of a system, it will provide certain satisfaction for its users.

2. System reliability, a reliable system is a system that has good resilience from all existing problems and provides the best service for its users.

3. Flexibility, the ability of a system to make changes according to customer needs to give satisfaction to its users.

4. Speed Time, the speed of time in accessing a system is one indicator of success in determining system quality.

5. System usability, the features and services available from a system are an indicator of system quality.

H2: There is a significant effect between variable system quality on digital wallet user satisfaction of students in Jakarta.

\section{Service Quality}

According to Murdick, Render, \& Russel (1990), the quality of a service or product is determined based on the user's point of view [10]. This states that the quality of service or a product needs to be user-oriented because the good or bad of a service or product is determined based on the user's point of view.
The quality of service can be measured through the following indicators:

1. Assurance, assurance in service quality includes the competence and credibility of an information system for user satisfaction.

2. Empathy, empathy in service quality includes user understanding, ease of access, and communication provided to users.

3. Responsiveness, responsiveness in service quality includes system alertness, system speed, and handling complaints related to information systems for user satisfaction.

H3: There is a significant effect between variable service quality on digital wallet user satisfaction of students in Jakarta.

\section{User Satisfaction}

User satisfaction is used to measure success in terms of effectiveness [9]. Information system user satisfaction is obtained from the results of an opinion or response in the form of an assessment after the user uses the information system. The measurement of user satisfaction is carried out through the following indicators:

1. Satisfaction of users, satisfaction from user satisfaction of an information system is a natural thing that arises from within users after using an information system. With the emergence of this, it can be carried out an assessment of the information system in user satisfaction as well as indicating that the information system has succeeded in providing satisfaction to its users.

2. Efficiency and Effectiveness, user satisfaction can be achieved if an information system can assist users in carrying out related activities more efficiently and effectively.

\subsection{Transaction}

Transaction is something that can be found in everyday life. When a human being needs goods or services in fulfilling their needs, transactions must be carried out in orders to obtain this to meet human needs. Transactions include activities carried out by two parties between the seller and the buyer, by making exchanges based on mutually agreed agreements.

\subsection{Financial Technology}

Financial technology or fintech is a term used to mean that technology acts as a connector from the financial sector to its users or to the wider community [11]. According to Dhar \& Stein (2017), financial technology can be interpreted as a development that occurs in the financial sector, with the development of a business model that is integrated with 
technology, and has a use as an absence of intermediaries, such as changing the process of making and providing products and services from a company, tackling privacy concerns related to applicable laws and regulations, and opening-up opportunities for development in an inclusive manner [12]. Through this statement, financial technology can be concluded as a technology from the financial sector that connects the financial sector with its users in providing various products and services to make it easier for users to carry out financial activities.

\subsection{Digital Wallet}

A digital wallet is an application on a smartphone that can be used to transact online. A digital wallet is an electronic service that functions as a data storage place for payment instruments, such as payments via cards, and is used as a storage area for funds to prepare for payment transactions [13]. In Indonesia, there are 4 digital wallets with the most users in 2019. The 4 digital wallets are Gopay, OVO, DANA, and LinkAja.

\section{RESEARCH METHODOLOGY}

In this research, researchers will use quantitative research methods. This method is used to determine the effect of information quality, system quality, and service quality on digital wallet user satisfaction of students in Jakarta. A questionnaire will be created based on DeLone and McLean's success model using 3 dimensions, namely: information quality, system quality, and service quality as a measure of user satisfaction. After the questionnaire is generated, it will be distributed randomly to students in Jakarta who use digital wallets to make transactions. After the data is successfully obtained, data processing and analysis will be carried out to get the desired results.

Smart PLS is used in data analysis because it will use multivariate analysis techniques with predetermined variables in it. Validity test and reliability test will be used to measure the correlation or connection between research variables. The Likert scale is the scale used. It is based on strongly disagree to strongly agree from 1 to 5 .

Data collection was carried out using Google Form to distribute questionnaires online. Respondents of this study were students located in Jakarta who used digital wallets. As for the results of data collection carried out through distributing questionnaires online, there were 100 respondents who participated. Thus, the total respondents used in this study were 100 respondents.

\subsection{Validity Test (Average Variance Extracted)}

The validity test will be measured with a limit of Average Variance Extracted (AVE) of 0.5. If the Average Variance Extracted shows a value of $\geq 0.5$, then the indicator can be declared valid.
Table 1: Average Variance Extracted

\begin{tabular}{|c|c|}
\hline Research Variable & $\begin{array}{c}\text { Average Variance } \\
\text { Extracted }\end{array}$ \\
\hline Information Quality (X1) & 0,648 \\
\hline System Quality (X2) & 0,576 \\
\hline Service Quality (X3) & 0,706 \\
\hline User Satisfaction (Y) & 0,626 \\
\hline
\end{tabular}

\subsection{Discriminant Validity Test}

In the discriminant validity test, it was carried out by looking at the cross-loading value of construct measurements or latent variables. The measurement model can be judged to have good discriminant validity if the relationship between constructs or latent variables with each indicator is higher than the relationship with each indicator of the construct or other latent variables.

Table 2: Cross Loading

\begin{tabular}{|c|c|c|c|c|}
\hline \multirow{2}{*}{ Indicator } & \multicolumn{4}{|c|}{ Variable } \\
\hline & X1 & $\mathrm{X2}$ & X3 & $\mathbf{Y}$ \\
\hline $\mathrm{X} 1 \mathrm{~A}$ & $\begin{array}{c}0,78 \\
2\end{array}$ & 0,719 & $\begin{array}{c}0,58 \\
6\end{array}$ & $\begin{array}{c}0,76 \\
8\end{array}$ \\
\hline X1B & $\begin{array}{c}0,82 \\
8\end{array}$ & 0,729 & $\begin{array}{c}0,39 \\
1\end{array}$ & $\begin{array}{c}0,76 \\
1\end{array}$ \\
\hline $\mathrm{X} 1 \mathrm{C}$ & $\begin{array}{c}0,81 \\
5\end{array}$ & 0,688 & $\begin{array}{c}0,42 \\
3\end{array}$ & $\begin{array}{c}0,77 \\
2\end{array}$ \\
\hline X1D & $\begin{array}{c}0,79 \\
5\end{array}$ & 0,543 & $\begin{array}{c}0,35 \\
9\end{array}$ & $\begin{array}{c}0,69 \\
3\end{array}$ \\
\hline $\mathrm{X} 2 \mathrm{~A}$ & $\begin{array}{c}0,51 \\
6\end{array}$ & 0,706 & $\begin{array}{c}0,27 \\
9\end{array}$ & $\begin{array}{c}0,52 \\
7\end{array}$ \\
\hline $\mathrm{X} 2 \mathrm{~B}$ & $\begin{array}{c}0,60 \\
0\end{array}$ & 0,835 & $\begin{array}{c}0,46 \\
0\end{array}$ & $\begin{array}{c}0,66 \\
9\end{array}$ \\
\hline $\mathrm{X} 2 \mathrm{C}$ & $\begin{array}{c}0,64 \\
1\end{array}$ & 0,704 & $\begin{array}{c}0,46 \\
4\end{array}$ & $\begin{array}{c}0,61 \\
2\end{array}$ \\
\hline X2D & $\begin{array}{c}0,74 \\
5\end{array}$ & 0,796 & $\begin{array}{c}0,42 \\
2\end{array}$ & $\begin{array}{c}0,74 \\
9\end{array}$ \\
\hline $\mathrm{X} 2 \mathrm{E}$ & $\begin{array}{c}0,64 \\
2\end{array}$ & 0,745 & $\begin{array}{c}0,39 \\
4\end{array}$ & $\begin{array}{c}0,70 \\
0\end{array}$ \\
\hline $\mathrm{X} 3 \mathrm{~A}$ & $\begin{array}{c}0,44 \\
1\end{array}$ & 0,486 & $\begin{array}{c}0,76 \\
2\end{array}$ & $\begin{array}{c}0,49 \\
8\end{array}$ \\
\hline X3B & $\begin{array}{c}0,42 \\
4\end{array}$ & 0,385 & $\begin{array}{c}0,87 \\
4\end{array}$ & $\begin{array}{c}0,45 \\
4\end{array}$ \\
\hline $\mathrm{X} 3 \mathrm{C}$ & $\begin{array}{c}0,50 \\
7\end{array}$ & 0,471 & $\begin{array}{c}0,87 \\
9\end{array}$ & $\begin{array}{c}0,55 \\
7\end{array}$ \\
\hline $\mathrm{Y} 1$ & $\begin{array}{c}0,75 \\
5\end{array}$ & 0,693 & $\begin{array}{c}0,37 \\
4\end{array}$ & $\begin{array}{c}0,79 \\
5\end{array}$ \\
\hline $\mathrm{Y} 2$ & $\begin{array}{c}0,69 \\
2\end{array}$ & 0,670 & $\begin{array}{c}0,46 \\
0\end{array}$ & $\begin{array}{c}0,72 \\
1\end{array}$ \\
\hline Y3 & $\begin{array}{c}0,73 \\
4\end{array}$ & 0,677 & $\begin{array}{c}0,51 \\
3\end{array}$ & $\begin{array}{c}0,74 \\
5\end{array}$ \\
\hline Y4 & $\begin{array}{c}0,69 \\
8\end{array}$ & 0,659 & $\begin{array}{c}0,52 \\
1\end{array}$ & $\begin{array}{c}0,72 \\
5\end{array}$ \\
\hline Y5 & $\begin{array}{c}0,75 \\
9\end{array}$ & 0,717 & $\begin{array}{c}0,51 \\
2\end{array}$ & $\begin{array}{c}0,88 \\
1\end{array}$ \\
\hline Y6 & $\begin{array}{c}0,77 \\
3\end{array}$ & 0,694 & $\begin{array}{c}0,48 \\
4\end{array}$ & $\begin{array}{c}0,86 \\
3\end{array}$ \\
\hline
\end{tabular}




\subsection{Reliability Test (Cronbach's Alpha)}

In the reliability test, it was carried out by looking at the results of the Cronbach's alpha value. A variable can be declared reliable if it has a Cronbach's alpha value $\geq 0.7$.

Table 3: Cronbach's Alpha

\begin{tabular}{|c|c|}
\hline Research Variable & Cronbach's Alpha \\
\hline Information Quality (X1) & 0,819 \\
\hline System Quality (X2) & 0,815 \\
\hline Service Quality (X3) & 0,789 \\
\hline User Satisfaction (Y) & 0,878 \\
\hline
\end{tabular}

\subsection{Composite Reliability Test}

A variable can be declared reliable if it has a composite reliability value $\geq 0.7$.

Table 4: Composite Reliability

\begin{tabular}{|c|c|}
\hline Research Variable & Composite Reliability \\
\hline Information Quality (X1) & 0,880 \\
\hline System Quality (X2) & 0,871 \\
\hline Service Quality (X3) & 0,877 \\
\hline User Satisfaction (Y) & 0,909 \\
\hline
\end{tabular}

\subsection{Structural Model}

In the research structural model, it is shown that the User Satisfaction variable $(\mathrm{Y})$ is measured by 3 other variables, namely Information Quality (X1), System Quality (X2), and Service Quality (X3). For each variable, there are indicators in it. The relationship between each variable and the indicators therein is connected using arrows to show the connectivity that occurs.

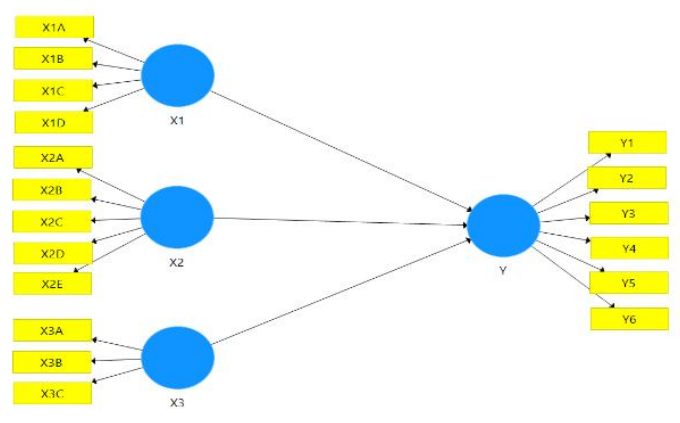

Figure 2: Structural Model

\section{RESULT AND DISCUSSION}

The result of this research can be seen through coefficient of determination (R-Square) and path coefficient. Coefficient of determination and path coefficient will be stated as below. The test of determination or the results of the R-Square value in this study is shown as follows:
Table 5: Coefficient of Determination (R-Square)

\begin{tabular}{|c|c|c|}
\hline & R Square & $\begin{array}{c}\text { R Square } \\
\text { Adjusted }\end{array}$ \\
\hline User Satisfaction & 0,901 & 0,897 \\
\hline
\end{tabular}

In the table of the results of the R-Square value, it can be seen that the variation in User Satisfaction (Y) is explained by the variation in the independent variable of 0.901 (90.1\%). The rest, namely $9.9 \%$, was delivered by independent variables that were not included in the research structural model.

The results of the Path Coefficient value for evaluating the structural model in this study are shown as follows:

Table 6: Path Coefficient

\begin{tabular}{|c|c|c|c|c|c|}
\hline No. & Hypothesis & $\begin{array}{c}\text { Origina } \\
\mathbf{1} \\
\text { Sample }\end{array}$ & $\begin{array}{c}\mathbf{T} \\
\text { Statistic } \\
\mathbf{S}\end{array}$ & $\begin{array}{c}\mathbf{P} \\
\text { Values }\end{array}$ & Result \\
\hline 1. & $\mathrm{X} 1$-> Y & 0,650 & 8,976 & 0,0000 & $\begin{array}{c}\text { Significan } \\
\mathbf{t}\end{array}$ \\
\hline 2. & $\mathrm{X} 2->\mathrm{Y}$ & 0,268 & 4,426 & 0,0000 & $\begin{array}{c}\text { Significan } \\
\mathbf{t}\end{array}$ \\
\hline 3. & $\mathrm{X} 3->\mathrm{Y}$ & 0,102 & 2,385 & 0,0180 & $\begin{array}{c}\text { Significan } \\
\mathbf{t}\end{array}$ \\
\hline
\end{tabular}

H1: There is a significant effect between variable information quality on digital wallet user satisfaction of students in Jakarta.

In hypothesis 1 , it is stated that there is a significant effect between the Information Quality variable (X1) on User Satisfaction (Y) digital wallets of students in Jakarta. Based on the tests that have been carried out and the results obtained, it is found that the relationship between the Information Quality variable (X1) and User Satisfaction (Y) has a T-Statistical value $>1.96$ of 8.976 and a $\mathrm{P}$-Value $<0.05$ of 0.0000 . Thus, based on these results, the hypothesis $\mathrm{H} 1$ is accepted where Information Quality (X1) has a significant effect on User Satisfaction (Y).

H2: There is a significant effect between variable system quality on digital wallet user satisfaction of students in Jakarta.

In hypothesis 2, it is stated that there is a significant effect between the System Quality (X2) variable on User Satisfaction (Y) digital wallets of students in Jakarta. Based on the tests that have been carried out and the results obtained, it is found that the relationship between the System Quality (X2) variable and User Satisfaction (Y) has a T-Statistical value $>1.96$ of 4.426 and a P-Value $<0.05$ of 0.0000 . Thus, based on these results, the hypothesis $\mathrm{H} 2$ is accepted where System Quality (X2) has a significant effect on User Satisfaction (Y). 
H3: There is a significant effect between variable service quality on digital wallet user satisfaction of students in Jakarta.

In hypothesis 3 , it is stated that there is a significant effect between the Service Quality (X3) variable on User Satisfaction (Y) digital wallets of students in Jakarta. Based on the tests that have been carried out and the results obtained, it is found that the relationship between the Service Quality (X3) variable and User Satisfaction (Y) has a T-Statistical value $>1.96$ of 2.385 and a $\mathrm{P}-\mathrm{Value}<0.05$ of 0.0180 . Thus, based on these results, the hypothesis H3 is accepted where Service Quality (X3) has a significant effect on User Satisfaction (Y).

\section{CONCLUSION}

Based on the research that has been conducted on digital wallet user satisfaction of students in Jakarta, the following conclusions can be drawn:

1. Through the research results, it is found that information quality variable on user satisfaction has a T-statistic value > 1.96 of 8.976 and a P-value $<0.05$ of 0.0000 . Thus, the information quality variable has a significant effect on digital wallet user satisfaction of students in Jakarta.

2. Through the research results, it is found that system quality variable on user satisfaction has a T-statistic value $>1.96$ of 4.426 and a P-value $<0.05$ of 0.0000 . Thus, the system quality variable has a significant effect on digital wallet user satisfaction of students in Jakarta.

3. Through the research results, it is found that service quality variable on user satisfaction has a T-statistic value $>1.96$ of 2.385 and a P-value $<0.05$ of 0.0180 . Thus, the service quality variable has a significant effect on digital wallet user satisfaction of students in Jakarta.

4. Overall, the variables of information quality, system quality, and service quality have an effect of $90.1 \%$ on digital wallet user satisfaction of students in Jakarta. The remaining $9.9 \%$ is influenced by other variables not included in this research model.

For further research related to digital wallet user satisfaction, can be used other variables in DeLone and McLean's success model that are not used in this research model, for better examining user satisfaction.

\section{REFERENCES}

[1] Dyahrini, W., \& Rachman, I. Efficiency in Payment Transactions using Queuing Models in Supermarket X. Pengertian Transaksi pembayaran, 4, 2012.
[2] Beritagar. Transaksi Uang Elektronik, 2009-2019. Retrieved 2019, from https:// lokadata.beritagar.id/chart/preview/transaksi-uang-e lektronik-2009-2019-1569298178

[3] Department, S. R. Number of Smartphone Users in Indonesia from 2015 to $\mathbf{2 0 2 5}$. Retrieved 2020, from https://www.statista.com/statistics/266729/smartpho ne-users-in-indonesia/

[4] Ludwianto, B. Milenial Dominasi Pengguna Internet Indonesia, 49\% Pernah Alami Bully. Retrieved 2019, from https://kumparan.com/kumparantech/milenial-domi nasi-pengguna-internet-indonesia-49-pernah-alamibully-1r5a51IREcH

[5] Catriana, E. Studi: 68 Persen Pengguna Dompet Digital adalah Milenial. Retrieved 2020, from https://money.kompas.com/read/2020/02/12/131300 826/studi--68-persen-pengguna-dompet-digital-adal ah-milenial

[6] Jayani, D. H. Inilah Dompet Digital yang Paling Banyak Digunakan. Retrieved 2019, from https://databoks.katadata.co.id/datapublish/2019/11/ 27/inilah-dompet-digital-yang-paling-banyak-digun akan

[7] Oktavianti, G. Pengantar Sistem Informasi. Pengantar Sistem Informasi, 30, 2019.

[8] Ramadhan, H. M., Astuti, E. S., \& Riyadi. Analisis implementasi sistem informasi klaim pada asuransi syariah (Studi Kasus Pada Asuransi Takaful Umum Kantor Pemasaran Surabaya). 1-12, 2013.

[9] DeLone, W. H., \& McLean, E. R. The DeLone and McLean Model of Information Systems Success: A Ten-Year Update. Journal of Management Information Systems, 19(4), 9-30, 2003.

[10] Murdick, R. G., Render, B., \& Russsel, R. S. Service Operations Management. New Jersey: A Division of Simon and Scuter, 1990.

[11] Abyan, M. A. Konsep Penggunaan Financial Technology dalam Membantu Masyarakat Sub Urban di Indonesia dalam Melakukan Transaksi Finansial. ResearchGate, 1-8, 2018.

[12] Dhar, V., \& Stein, R. M. FinTech Platforms and Strategy. Communications of the ACM, (10), 32-35, 2017.

[13] Febrilia, I., Pratiwi, S. P., \& Djatikusumo, I. Minat Penggunaan Cashless Payment System -Dompet Digital Pada Mahasiswa Di FE UNJ. Jurnal Riset Manajemen Sains Indonesia (JRMSI), 11(1), 1-19, 2020. 